\title{
Determinants of Sustainable Use of Farmlands in Amhara Region, Ethiopia
}

\author{
Ermias Ashagrie Abebe ${ }^{1 *}$ (D)
}

${ }^{1}$ Bahir Dar University, ETHIOPIA
${ }^{*}$ Corresponding Author: ermiashaa@gmail.com

Citation: Abebe, E. A. (2022). Determinants of Sustainable Use of Farmlands in Amhara Region, Ethiopia. European Journal of Sustainable Development Research, 6(2), em0182. https://doi.org/10.21601/ejosdr/11822

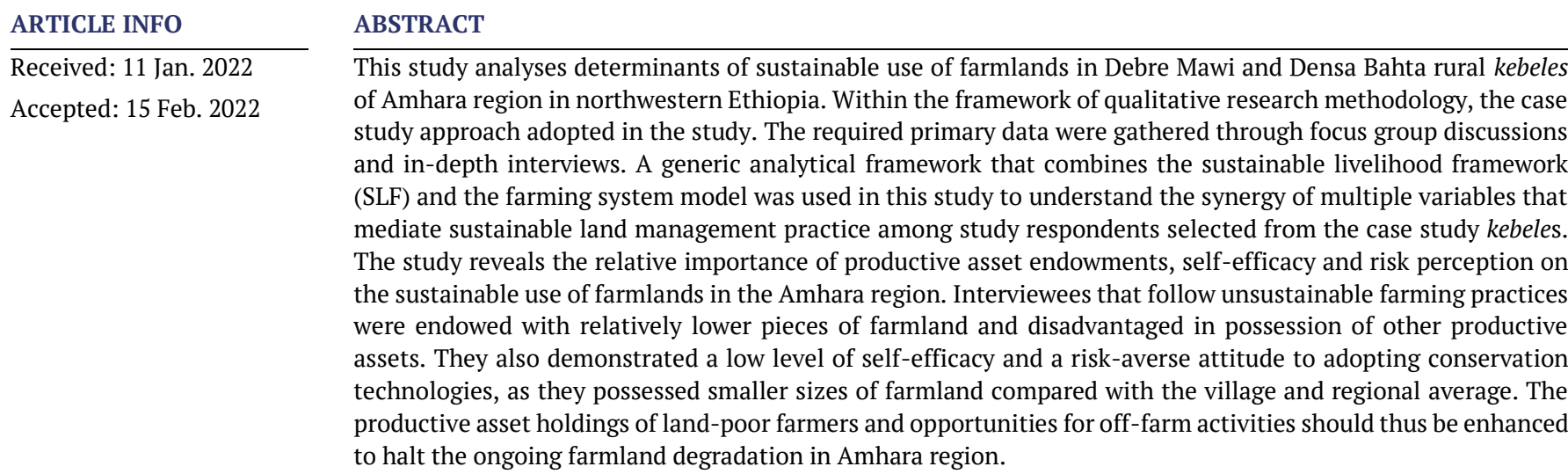

Keywords: conservation technologies, land tenure, land titling, sustainable land use

\section{INTRODUCTION}

\section{Background of the Study}

In the discourse of sustainable development, developing countries are challenged by closely related and critical problems of low agricultural production, poverty and land degradation (Pender and Gebremedhin, 2007; Perrt and Stevens, 2006; Readdson and Vositi, 1995; Scherr, 2000; Shiferaw and Holden, 2000). The neoliberal development orthodoxy is influencing land reform policies of the developing world towards uniformity to ameliorate these interwoven problems of underdevelopment (Bugri, 2008; Place, 2009). Likewise, a large-scale rural land certification and registration scheme was launched in Ethiopia to enhance the perception of security of tenure among smallholders in order to improve agricultural production and sustainable land use.

The way in which land tenure is instituted and the consequent perception of tenure security among landholders may directly affect the way in which farmlands are managed (Besley, 1995; Platteau, 1996; Sjaastad and Bromley, 1997). This may have consequences on efficiency as well as sustainability (Deininger and Jin, 2006; Holden and Yohannes,
2002). To enhance the perception of tenure security among landholders, there is a movement towards formalizing rural land holdings through registered title (Atwood, 1990; Fitzpatrick, 2006; Place, 2009; Platteau, 1996). Land tenure security that accrues from land registration removes uncertainty over whether landowners can reap the benefits of their long-term investments (Besley, 1995; Deininger and Jin, 2006; Feder and Nishio, 1998). In view of this, the registration scheme was launched in Ethiopia to enhance the perception of security of tenure among smallholders in order to improve agricultural production and sustainable use of farmlands (Deininger et al., 2011).

However, the literature on the relationship between security of tenure and sustainable land management has yielded inconclusive results in the African context. This is partly because the efficacy of land policy in advancing agricultural development and sustainable land management practices depends on other variables, including socio-cultural, political, and geographical factors (Bugri, 2008; Gebreselassie, 2006; Place, 2009). Heltberg (2002) notes three sets of reasons for the empirical evidence that do not support to the positive impacts of land titling on conservation investment in the context of Africa. First, communal ownership may give sufficient security of tenure than land tiling in Africa. Second, 
distortions in the implementation process of land titling programs may lead to increased conflict and insecurity of tenure. Third, African agriculture is facing other more urgent constraints than land rights. Accordingly, there are more factors that affect tenure security and more factors are influencing investment decisions than just security of tenure (Meinzen-Dick et al., 2002 cited in Bugri, 2008: 272). For example, Holden and Yohannes (2002) concluded that resource poverty in land, livestock and basic education, rather than tenure insecurity, may undermine investment in treeplanting and purchase of farm inputs in Southern Ethiopia. In contrast, Gebremedhin and Swinton (2003) found that farmers' perceived tenure security in northern Ethiopia was significantly and positively associated with long-term durable soil conservation investments, but not with the degree of investment. Whereas, Ayalew et al. (2005) found that perceived transfer rights, rather than a short term threat of expropriation, have a statistically significant impact on longterm investment in Ethiopia.

In the context of the developing world, empirical information on the factors that determine farmers' decision on conservation investment is limited (Amsalu and de Graff, 2007; Pender and Kerr, 1998; Shiferaw and Holden, 1998). Literature also indicates that farmers rarely adopt the technical solutions offered by external agencies unless consideration is given to the various socio-economic, cultural and institutional, as well as biophysical and technical factors (Barbier et al, 1997; Perrt and Stevens, 2006; Shiferaw and Holden, 2000; van de Flier and Braun, 2002). Empirical works clearly pointed out that factors influencing adoption and continued use of conservation technologies are different (e.g., Amsalu and de Graff, 2007; Marenya and Barrett, 2007). Ecologically sustainable use of farmlands demands adoption and continued use of conservation technologies.

The author examined relevant literature to consolidate the necessary theoretical and analytical foundation in analysing individual and group motivations towards sustainable land management practices. Of which, the sustainable livelihoods framework (SLF) and the farming systems model are prominent ones. The SLF provided by DFID (2001) helps to understand the dynamic relationship among the vulnerability context, livelihood assets, transforming structures and processes, livelihood strategies, and livelihood outcomes. It thus sees farmers' motivations towards sustainable land management practices as the outcome not only of farmers' (resource users) decisions at local level, but also dynamic changes in the vulnerability context, status of livelihood assets possessed and changes in legislation and policy at the level of the national government. In addition, the farming system model developed by Leeuwis and Van den Ban (2004) asserts that knowledge and perceptions are not neutral, but are subject to social influences and related to social interest. It thus presupposes that the learning process of individual farmers is always changing with the deliberateness and consciousness dynamism of the social environment.

Against this background, the study applied a generic analytical framework to investigate and understand the variables and factors that affect the sustainable use of farmlands in Densa Bahta and Debre Mawi rural kebeles in Yilmana Densa district (woreda) of Amhara National Regional
State (hereafter referred to as Amhara region), Ethiopia. The analytical framework is developed by combining the SLF with the farming system model. The analytical framework helped to understand the synergy of multiple variables that mediate sustainable land management practice among study respondents selected from the case study kebeles.

\section{Statement of the Problem}

The Amhara region is located in northwestern Ethiopia, where agricultural lands have experienced extensive cultivation for centuries, causing high soil degradation. The region covers a total area of 152,560 square kilometres (BoFED, 2006) with an estimated population of 17.2 million in 2007 (FDRE-PCC, 2008). This accounts for roughly $23 \%$ of the total population of Ethiopia, while in terms of area, the region constitutes only $15 \%$ of the country (BoFED, 2011). Approximately $87 \%$ of the region's population are rural and are engaged principally in subsistence agriculture, while the remaining $13 \%$ are urban dwellers employed mainly in the industry and services sectors (BoFED, 2011, p. 4). The land tenure system, with state ownership of land as its main feature, is regarded as a major contributor to stagnant agricultural production, degradation of farmlands, and agrarian immobility in the region (EEA, 2002; Gebreselassie, 2006; Rahmato, 2009).

The Amhara land registration and certification programme started in 2003. By late 2005, 2.4 million households (79\%) had been registered, 1.3 million provisional certificates had been issued free of charge, and common property resources had been demarcated (Deininger et al., 2008). A major feature of the programme is low-cost and decentralized implementation through elected land-use and administration committees (LACs) at village level (see Deininger et al., 2008, 2011). The programme promotes gender equality by issuing a land certificate that assures joint land ownership of spouses. All these attempts aim primarily at enhancing tenure security for increased investment and sustainable land use, but do not provide the farmer with rights to mortgage or sell the land. The programme thus departs from the approach of traditional land titling that is common elsewhere by issuing non-alienable use right certificates rather than full title deeds.

The effect of land tenure security, which is expected to accrue from land registration and certification, on sustainable land management is a contentious area in the literature. This is mainly because of the inconclusive empirical results that arise from methodological and contextual differences. This study followed a qualitative research methodology and approach in which a case study design was used. The study is limited to observing and understanding the determinants of sustainable use of farmlands in Densa Bahta and Debre Mawi rural kebeles in Yilmana Densa district (woreda) of Amhara National Regional State (hereafter Amhara region).

The research problem of this study is what determines ecologically sustainable use of farmlands in Amhara region in northwestern Ethiopia. In doing so, the research deals with the following research questions:

1. What kind of analytical framework helps to identify variables and factors that determine sustained adoption of conservation investment for the sustainable use of farmlands? 
2. Which variables and factors affect farming and sustainable land-use practices in Amhara region?

3. Which measures could be implemented to promote ecologically sustainable farmland-use practices in Amhara region?

\section{Research Objectives}

The primary objective of this study is to analyse the determinants of sustainable use of farmlands in Debre Mawi and Densa Bahta kebeles of Amhara region (case study sites selected from Yilmana Densa woreda in northwestern Ethiopia). To achieve the primary objective, these secondary objectives have been set:

1. To investigate variables and factors that affect the sustainable use of farmlands in Amhara region by using a generic analytical framework.

2. To recommend policy guidelines to promote ecologically sustainable use of farmlands in Amhara region.

\section{RESEARCH METHODOLOGY}

The research methodology is informed by the interpretivism paradigm, which appreciates the diversity of human experience within their lived reality. The overall approach is qualitative research, in which a case study design is used (Babbie, 2010; Creswell, 2009; Sarantakos, 1998). Qualitative research involves studies that do not attempt to quantify their results through statistical summary or analysis, but are characterized by adherence to a diverse array of orientations and strategies for maximizing the trustworthiness of study procedures and results (Babbie, 2010; Creswell, 2009).

Amhara is one of four major regions in Ethiopia in which the country has pursued a large-scale and aggressive land certification programme over the last decade (Deininger et al, 2011). Figure 1 shows the map of Ethiopia by regions. This region is characterized by homogeneous farming practice. The main ethnic groups in the region are the Amharas, who speak Amarigina (Amharic) as their first language and comprise 90\% of the region's population. Other ethnic groups include the Awi (Agew) people, who speak Agewigna; the Oromo, who

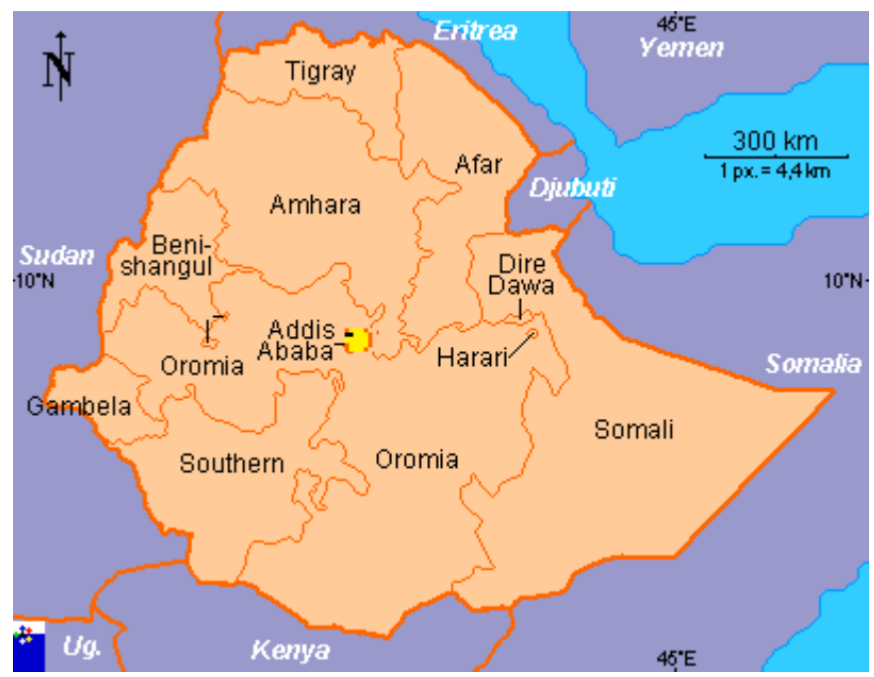

Figure 1. Map of Ethiopia by regions speak Afan Oromo; and many other smaller groups. Majority of the population of the region are followers of Orthodox Christianity, followed by Islam (BoFED, 2006; FDRE-PCC, 2008).

A topographic map was used to select the two case study sites from West Gojjam administrative zone of Amhara region (see Figure 2). These are Debre Mawi and Densa Bahta kebeles, which are located in Yilmana Densa woreda (see Figure 3 and Figure 4).

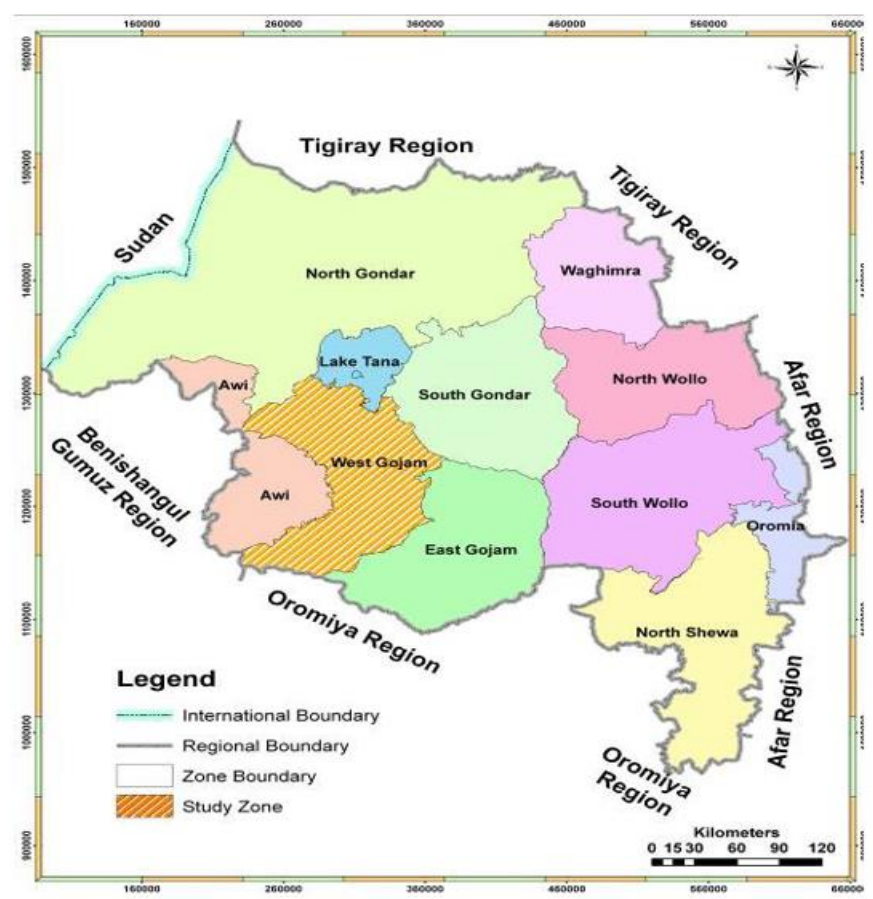

Figure 2. Map of Amhara region by administrative zones

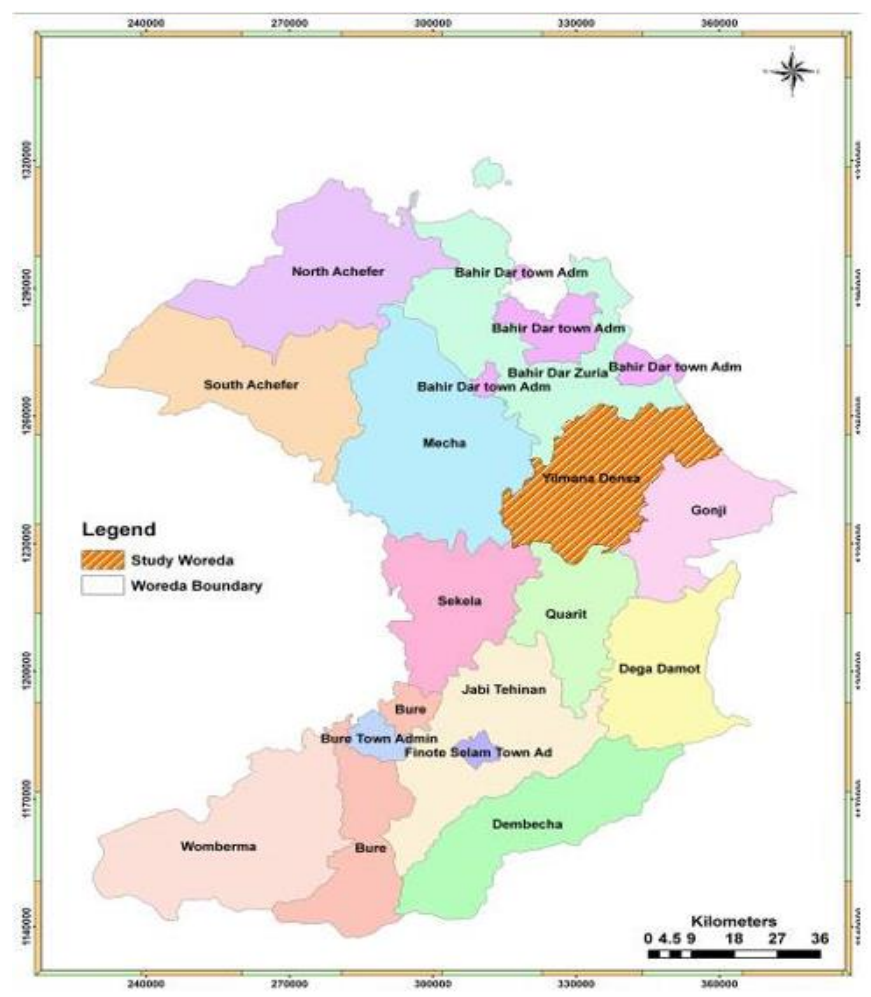

Figure 3. Map of West Gojjam administrative zone by woredas 


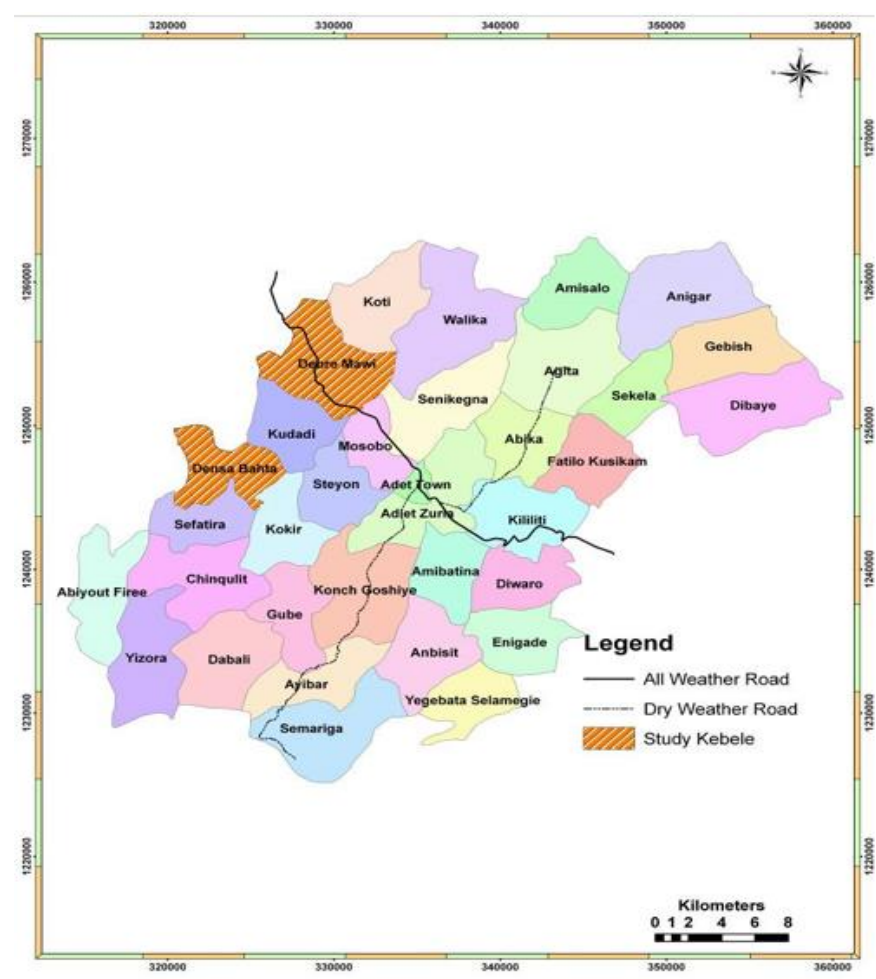

Figure 4. Map of Yilmana Densa woreda by kebeles

Debre Mawi is steeper and expected to have a shortage of arable land and higher land degradation. Densa Bahta is flat and assumed to have a better availability of arable land and relatively less land degradation. Thus, the main criteria used to select the study villages based on flatness and steepness of topography provide scientific validity to undertake a 'comparative case study' (Babbie, 2010: 311) in a qualitative field research.

Primary data were collected using participatory techniques such as participatory observation, focus group discussions (FGDs) and individual interviews. Study respondents (both group discussants and interviewees) were categorized into three land management practices, based on their performance in the last five of years. High performers are those respondents who undertook the construction and maintenance of various types of terraces on their holdings. Moderate performers are those respondents who constructed, but did not maintain various types of terraces on their holdings. Low performers are those respondents who had neither constructed nor maintained any type of terrace on their holdings in the last five years. In view of this, the high performers are those farmers that follow sustainable land management practice, whereas low performers are those farmers that follow unsustainable farming practice. The moderate performers are those farmers that have an intermediate position towards sustainable land management practice. Using a 'quota sampling' technique on these three categories of land management, a total of 48 study respondents were selected per study kebele, of which 18 participated in individual interviews and 30 in FGDs (Table 1).

The research adopted suitable analysis methods for both qualitative and quantitative data. Qualitative data were processed using 'coding' for 'discovering patterns' (see Babbie, 2010, p. 394-404) while quantitative data were analysed using appropriate statistical methods to interpret the extent, nature
Table 1. Distribution of study respondents across kebeles and land management strata

\begin{tabular}{lcccc}
\hline $\begin{array}{l}\text { Name of } \\
\text { study } \\
\text { kebele }\end{array}$ & $\begin{array}{c}\text { Land } \\
\text { management } \\
\text { strata }\end{array}$ & $\begin{array}{c}\text { Respondents } \\
\text { participated in } \\
\text { FGDs }\end{array}$ & $\begin{array}{c}\text { Respondents } \\
\text { participated in } \\
\text { the in-depth } \\
\text { interview }\end{array}$ & Total \\
\hline \multirow{2}{*}{$\begin{array}{l}\text { Hebre } \\
\text { Mawi }\end{array}$} & Moderate & 10 & 6 & 16 \\
\cline { 2 - 5 } & Low & 10 & 6 & 16 \\
\cline { 2 - 5 } & Total & $\mathbf{3 0}$ & 6 & 16 \\
\hline \multirow{2}{*}{$\begin{array}{ccccc}\text { Densa } \\
\text { Bahta }\end{array}$} & High & 10 & $\mathbf{1 8}$ & $\mathbf{4 8}$ \\
\cline { 2 - 5 } & Moderate & 10 & 6 & 16 \\
\cline { 2 - 5 } & Low & 10 & $\mathbf{1 8}$ & $\mathbf{4 8}$ \\
\hline
\end{tabular}

and pattern of relationship among variables of interest. In processing quantitative data, simple statistical tools, such as percentage, average, and cross-tabulation techniques were employed using the software package SPSS version 22.0 for social science research. Qualitative data is presented in the form of representative quote under themes results structured.

\section{RESULTS AND DISCUSSION}

A generic analytical framework was used in this study that combines the sustainable livelihood framework (SLF) of the Department for International Development (DFID, 2001) and the farming system model of Leeuwis and Van den Ban (2004). The analytical framework helped to understand the synergy of multiple variables that mediate sustainable land management practice among study respondents selected from the case study kebeles. Several factors thus mediate the sustainable use of farmlands in the study kebeles.

The pre-decisional processes are often influenced by factors that shape the behaviour of smallholders' towards a particular farming practice at a certain time. The inner circle in Figure 5 shows that 'knowledge and attitude', 'productive asset holdings', 'self-efficacy' and 'technology adoption and risk perception' mediate the decision of smallholders' towards a particular farming practice at a certain time.

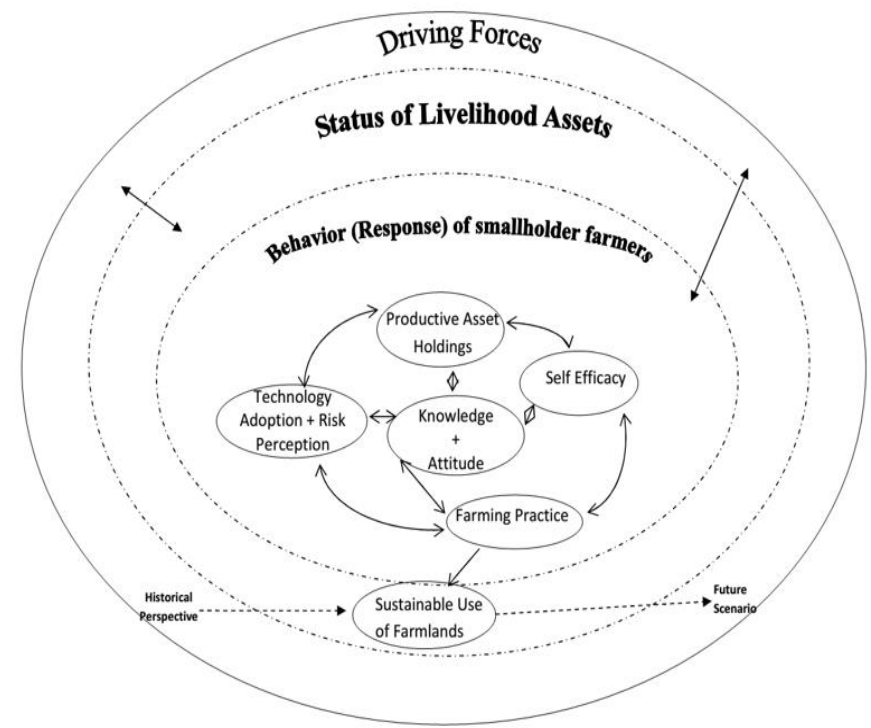

Figure 5. Analytical framework used in this study 
In simple terms, the pre-decisional processes correspond to those factors that mediate adoption of conservation technologies at a certain point in time. However, adoption of conservation technologies alone may not lead to sustainable use of farmlands unless the technologies are utilized continuously. A single- headed arrow that connects farming practice with sustainable use of farmlands, and a doubleheaded arrow that connects the middle circle with the outer circle in Figure 5 illustrates the dynamism of this postdecisional process for sustained use of conservation technologies.

\section{Driving Forces}

'Driving forces' have profound implications for the intermingled causes of rural poverty. Driving forces can be identified on three levels: macro, meso and micro. Driving forces originating at national or regional level for example land-use policy have 'downward' consequences on local farmers' use and management of land resources. Others originate at individual level with 'upward' consequences. For example, the number of children a woman has affects fertility rates and population growth, which have macro-level implications. Driving forces that originate at meso level, such as community land shortage, soil erosion and deforestation, can have consequences in both directions, such that households face land shortage (micro-level implications) and loss of agricultural production or productivity (macro-level implications).

Driving forces comprise three aspects: i) the vulnerability context associated with demography and land degradation; ii) shocks associated with droughts, flood, pest and diseases; iii) transforming structures and processes found at various spatial levels, such as laws, policies and institutions that allocate means of production and distribution of outputs. Driving forces or 'external conditioning variables' (Reardon and Vosti, 1995) are expected to be uniform for households in a particular agro-climatic or policy context. Likewise, the two case study kebeles have similar agro-climatic and policy contexts.

The vulnerability context associated with land degradation was high in the study kebeles. It was found that soil degradation is regarded as the second major environmental problem and was mentioned by $86.1 \%$ of interviewees. In addition, $39 \%$ of interviewees thought that conditions of soil degradation have worsened or worsened a lot in the past five years. This affirms that the current farming practice is the driving force since it determines the status of livelihood assets of farm households. This effect is represented in Figure 5 by a single-headed arrow that connects 'farming practice' to 'sustainable use of farmlands' and a double-headed arrow that connects the middle circle with the outer circle.

Driving forces arising from shocks, and transforming structures and processes shape the livelihood strategies of smallholders, and thus their farming practices in the study kebeles. Interviewees identified their most serious agricultural problems as lack of finance, pests and diseases, inadequate farmland and poor soil quality. Poor soil quality corresponds to driving forces arising from the vulnerability context. Lack of finance and inadequate farmland point to driving forces arising from transforming structures and processes. Pests and diseases indicate driving forces arising from shocks. It was found that pests and diseases were a priority problem, ranked first by one third of interviewees from high and moderate land management strata. However, lack of finance and inadequate farmland were ranked first by interviewees from the low land management stratum. Policies that aim at achieving sustainable livelihood outcomes should aim at increasing the productive asset endowments of resource-poor farmers.

Some $36.4 \%, 41.7 \%$, and $54.5 \%$ of interviewees from high, moderate and low land management strata, respectively, experienced catastrophic shock after land registration and certification. The types of shock reported by all groups of interviewees were weather, pest and diseases. Interviewees from the low land management stratum exclusively reported types of shock as loss of livestock, illness and death of a family member. The process of impoverishment (that is, loss of assets and deteriorating living conditions) over time is exacerbated by natural calamities or shock for those farm households that follow unsustainable farming practice.

The issues of land shortage and inequitable land distribution were echoed by one third of group discussants from the low land management stratum and by $25 \%$ of interviewees who expressed their dissatisfaction with the current land tenure system. Group discussants drawn from the low land management stratum in both kebeles highlighted the issue of land shortage as a major impediment to adoption of conservation technologies. The average size of registered and certified farmland among interviewees from high, moderate and low land management strata was $1.2,1$, and 0.75 hectares, respectively. These results provide evidence of the possible negative effects of inequitable land allocation on adoption of conservation technologies. Households with low per-capita land holdings were probably in the low land management stratum. Lack of finance and inadequate farmland were ranked as serious problems by interviewees from the low land management stratum. The agricultural production of those farmers that follow unsustainable land-use practice was jeopardized by lack of finance and shortage of land. This hints at divergence between policy texts and development practice towards enhancing the productive assets of vulnerable and destitute households in the discourse of sustainable development. One third of interviewees believe that the current land tenure system is a constraint to improved and sustainable natural resource use and management. Equally, one third of interviewees believe that the current land tenure system is a constraint to improved agricultural production and productivity. From these results, one can deduce the possible negative impact of the current land tenure system on the sustainable use of farmlands in the study kebeles since land certification has failed to address inequality in possession of farmlands. Inequitable allocation of farmlands might also have an adverse effect on equity and efficiency aspects of resource use. The average size of farmland owned by interviewees from the low land management stratum was smaller than the average land holding size in the study kebeles and Amhara region. Provisional land certificates were provided to smallholders in the study kebeles based on the amount of farmland allocated to them in the 1997 land redistribution.

In contrast, it was found that land registration and certification scheme has contributed to a high perception of 
land tenure security across the three land management strata and the two case study kebeles (see Result 2, 4 and 5 below).

1. Result 2: No group discussant mentioned any similarity between the Derg regime (1974-1991) and the current land tenure registration and certification scheme; neither did any respondent mentioned that land was owned by the state in both regimes.

2. Result 4: The majority of interviewees (94\%) affirmed that their perception of security of land tenure under the current system was associated with their access to and use of land for farming, and not individual property rights.

3. Result 5: The perception of land tenure security was high across the two kebeles and the three land management strata since the attitude score of interviewees lies within a favourable range.

This high perception of land tenure security, along with the legal obligation of farmers have to adopt proper land management practices, has contributed to improved adoption of sustainable farming practices in the post certification period. Therefore, the current land tenure system is an important driving force that has both positive and negative impacts on sustainable use of farmlands. The positive impact of the current land tenure system is two pronged. First, land certification has shown an assurance effect to enhance the perception of land tenure security among farmers in the study kebeles. Second, provision of the land certificate imposed a legal obligation on local farmers to adopt proper land management practices. The negative impact of the current land tenure system arises from its failure to reconsider the land holding size of a few disadvantaged farm households in the 1997 land redistribution. Provisional land certificates were provided to farmers in the study kebeles based on their land holding size in the 1997 land redistribution.

The above findings are in line with the analytical framework used in the study to examine the pre-decisional and post-decisional processes for the adoption and sustained use of conservation technologies. The pre-decisional processes are often mediated by factors that affect adoption of conservation technologies at a certain time. Adoption of conservation technologies alone may not lead to sustainable use of farmlands unless the technologies are utilized continuously. The dynamism of this post-decisional process for sustained use of conservation technologies is represented by a doubleheaded arrow that connects the outer circle (driving forces) with the inner circle (behaviour or response of smallholders), and a single arrow that connects farming practice with sustainable use of farmlands in Figure 5. In view of this, based on the empirical results discussed in this section, one can deduce that the post-decisional processes for sustained use of conservation technologies could be mediated by driving forces arising from these aspects:

1. The vulnerability context of land degradation.

2. Shocks in the form of loss of livestock, illness and death of a family member.

3. Transforming structures and processes such as current land-use policy and institutional credit facilities.

\section{Knowledge and Attitude}

The study measured respondents' knowledge of and attitude towards land tenure security and sustainable use of farmlands from their responses to statements and questions in the primary data-gathering instruments. Knowledge was measured from responses to questions of perceptions about soil degradation, land tenure security and conservation technologies. Attitude was measured from responses to questions of behavioural responses about soil degradation, land tenure security and conservation technologies. The findings are summarized below:

1. Result 1: No group discussant mentioned any similarity between the Derg and the current land tenure systems, and no one mentioned that land was owned by the state in both regimes.

2. Result 4: The majority of interviewees (94\%) affirmed that their perception of security of land tenure was associated with their access to and use of land for farming.

3. Result 5: The perception of land tenure security was high across the two kebeles and the three land management strata since the attitude score of interviewees lies within a favourable range.

4. Result 8: The six FGDs conducted across kebeles and land management strata show group discussants' similar knowledge of the features of sustainable farmland and the presence of unsustainable land management practices in the study kebeles.

5. Result 9: Group discussants across kebeles and land management strata demonstrated their understanding of the causes and manifestations of soil erosion in their locality.

6. Result 10: Interviewees drawn from the two case study kebeles and three land management strata have more or less similar knowledge of the outcomes and manifestations of soil erosion.

7. Result 15: A decade ago, group discussants' knowledge of conservation technologies was confined to traditional drainage furrows across kebeles and land management strata.

8. Result 16: Group discussants' knowledge of conservation technologies is enhanced through the agricultural extension programme, which acquaints them with physical and biological soil conservation technologies.

9. Result 17: A significant majority of interviewees demonstrated favourable attitudes towards conservation technologies.

10. Result 23: Interviewees from both kebeles have positive attitudes to the adoption and use of terrace construction, crop rotation, tree planting, intercropping, and application of manure during the post certification period.

11. Result 24: All interviewees have expressed their plan to keep on practising these sustainable land management practices for the coming five years. 
12. Result 26: Group discussants and interviewees drawn from the two kebeles and three land management strata demonstrated sufficient knowledge of short-term and long-term benefits of sustainable farming.

Farmers' knowledge of soil degradation, land tenure security and conservation technologies was similar across the three land management strata and the two case study kebeles. They have a positive attitude towards conservation technologies and sustainable land management practices. This can be ascribed to the uniform effect of several driving forces in shaping the knowledge and attitudes of farmers in an identical policy and agro-ecological environment (Reardon and Vosti, 1995). Farmers' adequate knowledge of and favourable attitudes towards soil conservation, land tenure security and conservation technologies contributed to improved adoption of sustainable farming practices in the post-certification period.

In contrast, the presence of unsustainable land management practices and soil degradation in the study kebeles implies that adequate knowledge and favourable attitudes could be mediated by another set of variables in the analytical framework among those farmers that follow unsustainable farming practice. This observation hints that a decision on a given farming practice requires a congruence of the other four sets of variables with adequate knowledge and favourable attitude. Thus, one may conclude that instead of a direct cause-effect relationship between knowledge and attitude to the one hand and farming practices on the other hand, there is a synergy among 'knowledge and attitude', 'productive asset holdings', 'risk perception and technology adoption' and 'self-efficacy' for a particular farming practice at a certain time. This dynamism of the pre-decisional process for adoption of conservation technologies is represented in the analytical framework by the double arrows connecting the variables included in the inner circle of Figure 5.

The findings provide empirical evidence for the farming system model introduced by Leeuwis and Van den Ban (2004). This model indicates that a variety of cultural, technical, economic and relational aspirations and preferences shape an individual farmer's land management practices. In contrast, the empirical result obscures the validity of assertions made by the economic theory of property rights. According to this theory, high perception of land tenure security automatically leads to enhanced agricultural production and sustainable use of farmlands. Though most study respondents perceived their land tenure security to be high, unsustainable land-use practices and soil degradation were evident in the study kebeles. This implies that enforcing land rights and obligations for proper farming practices is not sufficient to determine the adoption and sustained use of conservation technologies. In the context of the study kebeles, factors other than security of land tenure influenced farming practice. The analytical framework captured these other factors in the form of a set of variables, comprising driving forces, productive asset holdings, self-efficacy, and technology adoption and risk perception. The following section provides the findings and analysis regarding the productive asset endowments among interviewees drawn from three land management strata.

\section{Productive Asset Holdings}

The analytical framework considered six types of livelihood capitals: natural, physical, social, human, financial and cultural. The in-depth interview consisted of 25 open- and close-ended questions to measure and compare important aspects of these livelihood capitals that could determine the productive asset endowments of farm households. The term 'productive asset' refers to those aspects of livelihood capital that are used directly for agricultural production and affected by agricultural productivity.

The results show evidence of the effects of productive asset endowments on interviewees' farming practice. Table 2 summarizes the productive asset holding of the farmers in both kebeles using selected indicators for human, natural, physical, financial, social, and cultural capital. Table 2 shows a sharp contrast in possession of all six productive assets between interviewees from the high and low land management strata in the pre and post certification periods. Group discussants from the low land management stratum highlighted shortage of land as a major impediment to adopting conservation technologies. For example, 'lack of farmland is the most serious agricultural problem as some individuals in large families cannot have a piece of land for farming, let alone covering it by bunds' (FGD participant in Debre Mawi kebele). 'Shortage of farmland is a major impediment to adoption of terraces since terrace construction competes for the small plot I own' (FGD participant in Densa Bahta kebele). In addition, interviewees from the low land management stratum were in a disadvantageous position in terms of human, natural, physical, financial, social and cultural capital. The disadvantage of lack of productive assets directs their farming towards unsustainable land management practices, which reinforces their detrimental position and aggravates the low level of productive assets owned by these households. Lack of finance and inadequate farmland were ranked as serious problems by interviewees from the low land management stratum.

Table 2 shows that the average family size of the three groups of interviewees increased between the pre-and postcertification periods. This indicates a similar trend of the effect of driving forces associated with demography among the three groups of farmers. The increase of the average family size points to ever-increasing farming populations that are claimants to scarce farmlands. Population growth in the study kebeles may have a positive or a negative impact on the sustainable use of farmlands. Table 2 shows an increase in the possession of livestock between pre and post certification among interviewees from high and moderate land management strata (indicators 11 and 12). Conversely, these indicators show a decrease pattern among interviewees from the low land management stratum. There are two possible explanations. First, a dissimilar pattern of change on the selected indicator among the three groups of farmers may show that the effect of driving forces in mediating their access to productive assets or capitals was not uniform. Interviewees from the low land management stratum exclusively reported shock in the form of loss of livestock. Second, there might be a substitution between capitals and within a given capital. For example, a household might sell livestock and build a house (see indicators 13 and 14 in Table 2). 
Table 2. Distribution of important productive assets owned by interviewees in pre- and post-certification periods

\begin{tabular}{|c|c|c|c|c|c|}
\hline \multirow{2}{*}{ Number } & \multirow{2}{*}{ Indicators of variable of interest } & \multicolumn{3}{|c|}{ Land management strata } & \multirow{2}{*}{$\begin{array}{l}\text { Type of } \\
\text { capital }\end{array}$} \\
\hline & & High & Moderate & Low & \\
\hline 1 & Mean of the household head age & 47 & 39 & 45 & Human \\
\hline 2 & Mean of family size-post certification period & 8 & 6 & 5.73 & Human \\
\hline 3 & Mean of family size-pre certification period & 7.33 & 5.08 & 4.64 & Human \\
\hline 4 & Mean male household member-post certification period & 4 & 3.17 & 2.82 & Human \\
\hline 5 & Mean male household member-pre certification period & 3.58 & 2.5 & 2.45 & Human \\
\hline 6 & Mean female household member-post certification period & 3.92 & 2.83 & 2.91 & Human \\
\hline 7 & Mean female household member- pre certification period & 3.67 & 2.58 & 2.18 & Human \\
\hline 8 & Average farm size certified measured in quada & 6 & 4.2 & 3.2 & Natural \\
\hline 9 & Average farm size before certification & 6.15 & 4.18 & 3.63 & Natural \\
\hline 10 & Mean of per-capita farmland certified & 0.79 & 0.77 & 0.66 & Physical \\
\hline 11 & Mean of livestock owned measured in TLU-post certification & 5.17 & 3.77 & 2.59 & Physical \\
\hline 12 & Mean of livestock owned measured in TLU-pre certification & 5.1 & 2.8 & 3.75 & Physical \\
\hline 13 & Percentage of houses roofed with corrugated iron post certification & 91.7 & 100 & 83.3 & Physical \\
\hline 14 & Percentage of houses roofed with corrugated iron- pre certification & 75 & 50 & 33.3 & Physical \\
\hline 15 & Percentage of households who reported their access to credit services (borrowed) & 33.3 & 50 & 66.7 & Financial \\
\hline 16 & Proportion of households who lent at least 50 Birr in the last five years & 36.4 & 27.3 & 8.3 & Financial \\
\hline 17 & Proportion of households who adopted non-farm business before land certification & 27.5 & 25 & 25 & Financial \\
\hline$\overline{18}$ & Mean of per-capita annual expenditure in Birr (at the time of data collection) & 3,945 & 3,409 & 3,027 & Financial \\
\hline 19 & Mean value of tenure security index & 27.3 & 26.3 & 23.6 & Social \\
\hline 20 & Proportion of households included in the current agricultural extension program & 83.3 & 75 & 33.3 & Social \\
\hline 21 & Proportion of households who have an affiliation to a political party & 90.9 & 50.0 & 36.4 & Social \\
\hline 22 & Percentage of respondents who have a participation in Senbete & 45.5 & 41.7 & 36.4 & Social \\
\hline 23 & $\begin{array}{l}\text { Proportion of households who expressed their easily access to labour and livestock sharing } \\
\text { arrangements }\end{array}$ & 100 & 75.0 & 83.3 & Cultural \\
\hline
\end{tabular}

The literature (e.g., Fernandes and Woodhouse, 2008; Reardon and Vosti, 1995; Scherr, 2000; Wannasai and Shrestha, 2007; Vilei, 2011) reveals that the income and investment strategies of poor farmers are conditioned by a complex interplay of factors. The prevailing driving forces associated with vulnerability, shocks and transforming structures and institutions dictate the productive asset endowments of farm households. In addition, subsistence agricultural production and resource conservation technologies depend on household asset endowments and require modification of technical rates of substitution among livelihood assets, especially between human-made assets and natural resources. Differential access to productive asset holdings among farm households therefore affects the costs, returns and risks of conservation investments, and thereby the sustainable use of farmlands.

\section{Self-Efficacy}

The starting point of self-efficacy is assets or capital endowments owned, controlled, claimed or accessed by farm households. The prevailing driving forces in a given locality mediate these productive assets. Self-efficacy is measured in terms of ability to mobilize resources, availability of skills and competence, effectiveness of agro-support network and of (inter) community organizations (Leeuwis and Van den Ban, 2004). The research assessed the self-efficacy of interviewees based on indicators 20-23 in Table 2, and behavioural responses to in-depth interview questions.

Interviewees from the low land management stratum that follow unsustainable farming practices were disadvantaged in terms of the indicators of human, natural, physical, financial, social, and cultural capital (Table 2). This detrimental position reinforced their perceived lack of power to control environmental degradation in their community, based on the following results. Interviewees were asked whether their household had the required skills and competency to adopt conservation technologies. Approximately 67\%, 75\%, and $100 \%$ of interviewees from the low, moderate and high land management strata, respectively, reported that their household had the required skills and competency to adopt conservation technologies. In addition, interviewees were asked about their ability to mobilize local economic resources to construct conservation structures on their holdings. Approximately $75 \%, 83 \%$, and $100 \%$ of interviewees from the low, moderate and high land management strata, respectively, affirmed that they could easily mobilize local economic resources to balance deficits of their household to adopt conservation technologies. Most interviewees reported a favourable response to items designed to measure their selfefficacy. These results may arise from their legal obligations to adopt conservation technologies under the current land tenure system. Indicators 20, 21, 22, and 23 of Table 2 show the disadvantageous position of those interviewees that follow unsustainable farming practice regarding their access to an agro-support network and community level organizations. Indicator 20 shows that $83 \%$ and $33 \%$ of interviewees that follow sustainable and unsustainable farming practices, respectively, were included in the current agricultural extension programme. Indicator 21 shows that $91 \%$ and $36 \%$ of interviewees that follow sustainable and unsustainable farming practice, respectively, were affiliated to a political party. Indicator 22 shows that $46 \%$ and $36 \%$ of interviewees that follow sustainable and unsustainable farming practice, respectively, participate in Senbete (a CBO formed on the basis of the neighbourhood and church attendance). Indicator 23 shows that $100 \%$ and $83 \%$ of interviewees that follow sustainable and unsustainable farming practice, respectively, 
have easy access to labour and livestock sharing arrangements in their community.

Study respondents that follow unsustainable farming practice thus demonstrated a low level of self-efficacy in solving the problem of land degradation. This is because of their relatively disadvantageous position in possession of the six productive assets considered in this study. In addition, the process of impoverishment or depletion of productive assets is exacerbated by natural calamities or shock and low-level institutional support systems (agro-support network and community organizations) for respondents that follow unsustainable farming practice (see the last four indicators of Table 2). This unsustainable farming practice aggravates the low status of productive assets owned by these households, since land degradation perpetuates the vicious circle of low income and poverty. In the context of the study areas, where farmlands are the principal means of support for rural livelihoods, land degradation would become an adverse driving force that could result in lower agricultural output, lower farm income, lower nutritional status, poor health and reduced schooling for children, as well as fewer livestock and farm implements for the next production period. The SLA regards awareness of the productive assets of poor farmers as crucial to an understanding of the options open to them in sustainable land management (Ellis and Allison, 2004: 3).

\section{Technology Adoption and Risk Perception}

The research traced the patterns of adoption and rejection of conservation technologies, along with common justifications, in the pre- and post-certification periods. Adoption refers to the practice of households' investing in locally known conservation technologies, while rejection refers to their withdrawal from these practices. These technologies were disaggregated into terrace construction, crop rotation, fallowing, tree planting, inter-cropping, and application of manure on farm plots. The pattern of change towards sustainable farming practice in the post-certification period is ascribed to farmers' perception of risks. This is conditioned by factors associated with the synergy of the technical domain, economic domain and social organizational relationships. About the technical domain, it is indicated that group discussants abandoned traditional drainage furrows because of the observed soil erosion caused by the technology. Farmers discarded traditional drainage furrows after they obtained the technical knowhow of modern cut-off drain structures and graded terraces through the agricultural extension workers assigned to their locality. Over time, they have become convinced of the shortcomings of traditional drainage furrows and the advantages of modern cut-off drain structures and graded terraces. An economic reason that convinced farmers was the observed loss of agricultural output caused by soil erosion in their locality. They were also convinced because they realized there was unintended conflict with downstream farmers because of flood damage caused by the traditional drainage furrows.

The observed pattern of change in farming practice in the post-certification period may have arisen because of several factors. This could be due to farmers' obligation to adopt conservation technologies under the current land tenure system. In addition, the campaign that aims to cover sub- watersheds with physical conservation structures through administrative and authoritarian procedures might be responsible. Moreover, this could be because of the study respondents' knowledge of short-term and long-term benefits of sustainable farming.

Given the unanimous knowledge and attitudes of study respondents across kebeles and land management strata, driving forces of the external environment have shown profound effects on differential possession of productive assets among the three groups of farmers. The study affirmed the disadvantageous position of those farmers that follow unsustainable farming practice in the possession of the six productive assets. A set of variables that determine the productive asset holdings further dictate farmer's options and sustainable land management practice through their effect on self-efficacy and risk perception. The pre-decisional processes for adopting conservation technologies among those farmers that follow unsustainable farming practice were thus jeopardized by their disadvantageous position in possession of productive assets, their low level of self-efficacy and higher perception of risks since terrace construction and tree planting competes for the small farmland they possess. Above all, the pre-decisional processes for adoption of conservation technologies triggered by post-decisional processes among those farmers that follow unsustainable farming practice since land degradation depletes the status of their productive asset endowments.

Therefore, the study found that the driving forces of the external environment mediate the status of productive asset endowments among smallholders and shape their farming practices in the study areas. These practices determine the status of renewable natural capital (farmland) on which their livelihood depends. The status of this natural capital, along with other five forms of capital, determines the differential access to productive assets among these three groups of farmers considered in this study. The status of productive asset holdings could be mediated by several driving forces, and will shape farmers' future sustainable land management practices through its synergy with knowledge and attitudes, self-efficacy and risk perception. Study respondents' knowledge of and attitudes to security of land tenure and conservation technologies do not vary across the two kebeles and three groups of farmers. This hints at the relative importance of productive asset endowment, self-efficacy and risk perception on sustainable use of farmlands in Amhara region.

\section{CONCLUSIONS AND IMPLICATIONS}

The neoliberal development orthodoxy prescribes a suitable and stable property rights regime for sustainable land management practices, essentially on the grounds of double prongs. On the one hand, private property rights in land or land titling is considered 'capital' that induces further investment. On the other hand, it has a function in preempting potential discord and conflict between different tiers of land users/owners by specifying the rights and duties of those in each of the levels. In view of this, the notions that drive a policy discourse of rural land titling programme to 
redress the problem of farmland degradation is widely contested in both theoretical and empirical literature.

The economic theory of property rights applies the 'assurance', 'collateral' and 'efficiency or gains from trade' arguments to predict the effects of land tenure security on sustainable land management. In the context of the study area, where there is no property market, and the law prohibits the use of land as collateral, land titling may affect sustainable land management only through its assurance effect. Though most study respondents perceived their land tenure security to be high, poor agricultural production and environmental degradation were evident in the study kebeles. This reveals that the theory of property rights cannot assess the adequacy of land tenure security on sustainable farming practice in African rural situations on economic considerations alone. It emphasizes market-driven property rights, and ensuring the security and efficiency of land transactions, but overlooks important socioeconomic factors that affect how rural productive resources are accessed, used, and contested by individuals or households in support of their livelihoods.

The paper investigated factors that affect the sustainable use of farmlands in Amhara region with the aid of a generic analytical framework. The analytical framework was developed by combining the sustainable livelihood framework with the farming system model. The paper attempted to show that driving forces arising from land degradation; shocks such as loss of livestock, illness and deaths of family members; and transforming structures and processes such as the current land-use policy and institutional credit facilities, which could mediate sustainable farming practice in the case study kebeles. The current land-use policy has positive and negative impacts on sustainable use of farmlands in the study kebeles. The positive impact of the policy is its assurance effect in enhancing the perception of security of tenure among farmers, coupled with their legal obligation to adopt sustainable farming practice. The negative impact involves its failure to consider the size of land holding for a few disadvantaged households in the 1997 land redistribution. Small farm size and lower per-capita land holding were constraints to adopting conservation technologies.

There is a synergy between 'knowledge and attitude', 'productive asset holdings', 'risk perception and technology adoption' and 'self-efficacy' of farmers to adopt a particular farming practice at a certain time. Differential access to productive assets among farm households affects the costs, returns and risks of conservation investments, and thereby the sustainable use of farmlands. Study respondents that follow unsustainable farming practices were relatively disadvantaged in possession of all productive assets and demonstrated a low level of self-efficacy in solving the problem of land degradation. The pre-decisional processes for adoption of conservation technologies by these farmers were jeopardized by their higher perception of risks, since terrace construction and tree planting compete for their small farmland. The process of impoverishment or depletion of productive assets is exacerbated by natural calamities and the low level of institutional support system for respondents that follow unsustainable farming practice. This aggravates the low status of assets owned by these households since land degradation adversely affects the crop yield obtained from the plot.
Land tenure reform by itself is not a complete solution to the production and livelihood problems of households in rural Amhara in general and in the study areas in particular. It is not the only constraint on the production systems and livelihood strategies of rural households. Evidence from this paper has indicated that adoption and sustained use of conservation technologies by local farmers are not constrained by one variable, and therefore cannot be tackled by manipulating one key variable, but by dealing with several related variables. In view of this, the following recommendations are suggested to halt the ongoing farmland degradation in Amhara region:

1. Government intervention and land-use policy should be grounded on more rigorous and contextual study rather than ideological stands. Context-specific understanding of the dynamic interplay of several factors that resulted in an imbalance for the demand and supply of farmlands is thus vital in designing landuse policy and providing land certificates.

2. The productive asset holdings of land-poor farmers and opportunities for off-farm activities should be enhanced, given the socio-political environment and context, and current land registration and certification scheme, which does not allow for equitable land redistribution. Off-farm activities are thus important mechanisms to raise the productive assets and incomes of households that follow unsustainable farming and to halt ongoing land degradation in Amhara region.

3. Government should create conditions that enhance smallholders other forms of productive assets. These measures could include investing in agrarian services (roads, extension, improved access to inputs, training, marketing outlets), access to affordable credit, community-based management of natural resources, literacy, education, and basic health services. Therefore, enhancing the productive asset of farm households is crucial to ensuring sustainable use of farmlands in Amhara region. Investment on conservation technologies can be improved by introducing and coordinating financial intermediaries that provide earmarked credit for land-related investment.

Funding: No external funding is received for this article.

Declaration of interest: Author declares no competing interest. Ethics approval and consent to participate: Not applicable.

Availability of data and materials: All data generated or analyzed during this study are available for sharing when appropriate request is directed to the author.

\section{REFERENCES}

Amsalu, A. and de Graaff, J. (2007). Determinants of adoption and continued use of stone terraces for soil and water conservation in an Ethiopian highland watershed. Ecological Economics, 61(2-3), 294-302. https://doi.org/10. 1016/j.ecolecon.2006.01.014

Atwood, D. A. (1990). Land registration in Africa: The impact on agricultural production. World Development, 18(5), 659671. https://doi.org/10.1016/0305-750X(90)90016-Q 
Ayalew, D., Dercon, S. and Gautam, M. (2005). Property rights in a very poor country: Tenure insecurity and investment in Ethiopia. Policy Research Working Paper, 4363. Available at: https://openknowledge.worldbank.org/handle/10986/ 7361

Babbie, E. R. (2010). The practice of social research. Boston, MA: Wadsworth Publishing.

Barbier, E. B., Sanchez, P., Thomas, R. and Wagner, A. (1997). The economic determinants of land degradation in developing countries. Philosophical Transactions: Biological Sciences, 352(1356), 891-899. https://doi.org/10.1098/rstb. 1997.0068

Besley, T. (1995). Property rights and investment incentives: Theory and evidence from Ghana. Journal of Political Economy, 103(5), 903-936. https://doi.org/10.1086/262008

BoFED. (2006). Development indicators of Amhara region. Bahir Dar: ANRS-BoFED.

BoFED. (2011). Development indicators of Amhara Region. Bahir Dar: ANRS-BoFED.

Bruce, J. (1993). The variety of reform: A review of recent experience with land reform and the reform of land tenure, with particular reference to the African experience, in H. S. Marcussen (ed), Institutional issues in natural resource management. Roskilde: International Development Studies.

Bugri, J. T. (2008). The determinants of tenure security, agricultural production and environmental degradation in Africa: Evidence from stakeholders in north-east Ghana. Land Use Policy, 25, 271-285. https://doi.org/10.1016/j. landusepol.2007.08.002

Creswell, J. W. (2009). Research design: Qualitative, quantitative, and mixed methods approaches. Thousand Oaks, CA: SAGE.

Deininger, K. and Jin, S. (2006). Tenure security and landrelated investment: Evidence from Ethiopia. European Economic Review, 50(5), 1245-1277. https://doi.org/10.1016 /j.euroecorev.2005.02.001

Deininger, K., Ali, D. A. and Alemu, T. (2008). Assessing the functioning of land rental markets in Ethiopia. Economic Development and Cultural Change, 57(1), 67-100. https://doi.org/10.1086/590462

Deininger, K., Ali, D. A. and Alemu, T. (2011). Impacts of land certification on tenure security, investment, and land market participation: Evidence from Ethiopia. Land Economics, 87(2), 312-334. https://doi.org/10.3368/le.87.2. 312

DFID. (2001). Sustainable livelihoods guidance sheet. Available at: http://www.livelihoods.org/info/info_guidancesheets. html

EEA. (2002). A research report on land tenure and agricultural development in Ethiopia. Addis Ababa: EEA/EEPRI.

Ellis, F. and Allison, E. (2004). Livelihood diversification and natural resource access. LSP Working Paper, 9. Available at: https://www.fao.org/3/ad689e/ad689e.pdf

FDRE-PCC. (2008). Summary and statistical report of the 2007 population and housing census. Addis Ababa: UNFPA.
Feder, G. and Nishio, A. (1998). The benefits of land registration and titling: Economic and social perspectives. Journal of Land Use Policy, 15(1), 25-43. https://doi.org/10. 1016/S0264-8377(97)00039-2

Fernandes, L. and Woodhouse, P. J. (2008). Family farm sustainability in southern Brazil: An application of agrienvironmental indicators. Ecological Economics, 66(2-3), 243-257. https://doi.org/10.1016/j.ecolecon.2008.01.027

Fitzpatrick, D. (2006). Evolution and chaos in property rights systems: The third world tragedy of contested access. The Yale Law Journal, 115(5), 996-1048. https://doi.org/10.2307 /20455644

Gebremedhin, B.and Swinton, S. (2003). Investment in soil conservation in northern Ethiopia: The role of land tenure security and public programs. Agricultural Economics, 29(1), 69-84. https://doi.org/10.1111/j.1574-0862.2003. tb00148.x

Gebreselassie, S. (2006). Land, land policy and smallholder agriculture in Ethiopia: Options and scenarios. Available at: http://www.future-agricultures.org/pdf\%20files/ SG_paper_2.pdf

Heltberg, R. (2002). Property rights and natural resource management in developing countries. Journal of Economic Surveys, 16(2), 189-214. https://doi.org/10.1111/14676419.00164

Holden, S. and Yohannes, H. (2002). Land redistribution, tenure insecurity, and intensity of production: A study of farm households in southern Ethiopia. Land Economics, 78(4), 573-590. https://doi.org/10.2307/3146854

Leeuwis, C. and van den Ban, A. (2004). Communication for rural innovation: Rethinking agricultural extension. India: Blackwell Publishing. https://doi.org/10.1002/ 9780470995235

Marenya, P. P. and Barrett, C. B. (2007). Household level determinants of adoption of improved natural resource management practices among smallholder farmers in western Kenya. Food Policy, 32, 515-536. https://doi.org/ 10.1016/j.foodpol.2006.10.002

Pender, J. and Gebremedhin, B. (2007). Determinants of agricultural and land management practices and impacts on crop production and household income in the highlands of Tigray, Ethiopia. Journal of African Economies, 17(3), 395-450. https://doi.org/10.1093/jae/ejm028

Pender, J. L. and Kerr, J. M. (1998). Determinants of farmers' indigenous soil and water conservation investments in semi-arid India. Agricultural Economics, 19(1-2), 113-125. https://doi.org/10.1111/j.1574-0862.1998.tb00520.x

Perrt, S. R. and Stevens, J. B. (2006). Socio-economic reasons for low adoption of water conservation technologies by smallholder farmers in Southern Africa: A review of the literature. Development Southern Africa, 23(4), 461- 476. https://doi.org/10.1080/03768350600927193

Place, F. (2009). Land tenure and agricultural productivity in Africa: A comparative analysis of the economics literature and recent policy strategy and reforms. World Development, 37(8), 1326-1336. https://doi.org/10.1016/j.worlddev.2008. 08.020 
Platteau, J. P. (1996). The evolutionary theory of land rights as applied to sub-Saharan Africa: A critical assessment. Development and Change, 27(1), 29-86. https://doi.org/10. 1111/j.1467-7660.1996.tb00578.x

Platteau, J. P. (2000). Land tenure, economic growth and poverty in sub-Saharan Africa, in C. Toulmin and J. Quan (eds), Evolving land rights, policy and tenure in Africa, London: Department for International Development, International Institute for Environment and Development and Natural Resources Institute.

Rahmato, D. (2009). The peasants and the state: Studies in agrarian change in Ethiopia 1950s-2000s. Addis Ababa: Addis Ababa University Press.

Reardon, T. and Vosti, S. A. (1995). Links between rural poverty and the environment in developing countries: Asset categories and investment poverty. World Development, 23(9), 1495-1506. https://doi.org/10.1016/ 0305-750X(95)00061-G

Sarantakos, S. (1998). Social research. Melbourne: Macmillan. https://doi.org/10.1007/978-1-349-14884-4

Scherr, S. J. (2000). A downward spiral? Research evidence on the relationship between poverty and natural resource degradation. Food Policy, 25(4), 479-498. https://doi.org/ 10.1016/S0306-9192(00)00022-1

Shiferaw, B. and Holden, S. (1998). Resource degradation and adoption of land conservation technologies in the Ethiopian highlands: A case study in Andit Tid, North Shewa. Agricultural Economics, 18, 233-247. https://doi.org/10.1111/j.1574-0862.1998.tb00502.x
Shiferaw, B. and Holden, S. (2000). Policy instruments for sustainable land management: The case of highland smallholders in Ethiopia. Agricultural Economics, 22(3), 217-232. https://doi.org/10.1111/j.1574-0862.2000. tb00071.x

Sjaastad, E. and Bromley, D. (1997). Indigenous land rights in sub-Saharan Africa: Appropriation, security and investment demand. World Development, 25(4), 549-562. https://doi.org/10.1016/S0305-750X(96)00120-9

Sjaastad, E. and Bromley, D. (2000). The prejudices of property rights: On individualism, specificity, and security in property regimes. Development Policy Review, 18(4), 365389. https://doi.org/10.1111/1467-7679.00117

Van de Flier, E. and Braun, A. R. (2002). Conceptualizing integrative, farmer participatory research for sustainable agriculture: From opportunities to impact. Agriculture and Human Values, 19, 25-38. https://doi.org/10.1023/ A:1015081030682

Vilei, S. (2011). Local perceptions of sustainability of farming systems on Leyte, Philippines: Divergences and congruencies between different stakeholders. International Journal of Sustainable Development and World Ecology, (i first), 1-13. https://doi.org/10.1080/13504509.2011.555112

Wannasai, N. and Shrestha, R. P. (2007). Determinants of rural land-use change in Prasae watershed area of Thailand. Asia-Pacific Journal of Rural Development, 18(2), 47-60. https://doi.org/10.1177/1018529120070203 


\section{APPENDIX A}

\section{Topic Guide for Focus Group Discussion}

\section{Introduction: Brief the group about}

Ethical issues and objectives of the study

Do not need to come consensus or agreement, everyone's views are valued

Unless participants are unanimously willing, there will not be any kind of note taking and audio recording

Each participant has a role and responsibility to preserve privacy and confidentiality as much as possible

Disseminating someone's ideals within the village in the form of either joke or gossip is a punishable act under the law

\section{A. WARM UP}

Warm up the participants with the use of posters

Then, start the discussion with introductory session

Allow the participants to undertake an introductory session that includes introducing their name along with descriptions associated to

Type and amount (quantity) of conservation investment ${ }^{1}$ made on their plots

Their future plan or inclination towards undertaking conservation investments

\section{B. SPECIFIC QUESTIONS}

Is the existing land tenure system any different from the system that prevailed during the Derg?

If so, what are the differences and/or similarities among them?

Please, list down the types of land rights bestowed to you by land registration and certification scheme.

Do you think that there is soil degradation in the arable lands of your locality?

If yes, what are the major causes and manifestations?

How would you recognize a sustainable and unsustainable farmland from its appearance?

What economic, social and cultural advantages are experienced by farmers undertaking sustainable land management practices?

What types of soil and water conservation technologies (both traditional and modern) were used a decade ago in your locality for the purpose of sustainable management of farmlands?

What types of traditional and modern conservation technologies are currently common for the purpose of sustainable management of farmlands in your locality?

What are the reasons for observed patterns of change among current and earlier sustainable farming practices through the adoption and disadoption of conservation technologies in your locality?

(Optional question, if different answers (lists) are provided to question numbers 6 and 7)

How does land certification and registration scheme affect sustainable farming practice in your locality?

Note. ${ }^{1}$ These conservation investments include both traditional and modern technologies. The traditional measures include drainage furrows and the modern methods includes graded soil bunds, stone faced terraces, check dams and cut-off drain structures 


\section{APPENDIX B}

\section{Questionnaire for the Interview of Individual Farmers}

Greet the person you are interviewing and introduce yourself. Then, read aloud the following:

\section{Dear Sir/Madam,}

This questionnaire is designed to collect information about the impact of introducing land certificate on sustainable use of farmlands in your locality. This information will be used only for academic purpose and confidential. In addition, you are free to abstain to a question that demands a response beyond your personal perception. Thus, you are highly requested to provide your genuine response. Thank you in advance.

Name of enumerator Date of interview Signature

1. Respondents back ground information

Kebele 'Got'(Village)

2. How many family members do you have?

3. Could you please tell me the peculiar characteristics of your household members?

\begin{tabular}{|c|c|c|c|c|c|c|}
\hline \multirow[t]{2}{*}{ Household member } & \multicolumn{2}{|c|}{ Sex } & \multirow[t]{2}{*}{ Age } & \multirow{2}{*}{$\begin{array}{c}\text { Level of } \\
\text { education } \\
\text { (see code) }\end{array}$} & \multicolumn{2}{|c|}{ Occupation (see code) } \\
\hline & Male & Female & & & Main & Secondary \\
\hline \multicolumn{7}{|l|}{ Family head } \\
\hline \multicolumn{7}{|l|}{ Spouse } \\
\hline \multicolumn{7}{|l|}{ Children (a) } \\
\hline \multicolumn{7}{|l|}{ Children (b) } \\
\hline \multicolumn{7}{|l|}{ Children (c) } \\
\hline \multicolumn{7}{|l|}{ Children (d) } \\
\hline \multicolumn{7}{|l|}{ Children (e) } \\
\hline \multicolumn{7}{|l|}{ Other members (a) } \\
\hline \multicolumn{7}{|l|}{ Members (b) } \\
\hline \multicolumn{7}{|l|}{ Members (c) } \\
\hline Members (d) & & & & & & \\
\hline
\end{tabular}

Codes for education level and occupation

\begin{tabular}{lll}
\hline Level of education & Code & Type of occupation \\
\hline Illiterate & 1 & Farming \\
\hline Read and write & 2 & Petty trade \\
\hline Grade 1-4 & 3 & Hand craft and construction \\
\hline Grade 5-8 & 4 & Metal and woodwork \\
\hline Grade 9-12 & 5 & Non-farm wage employment \\
\hline $12^{+}$ & 6 & Others, specify \\
\hline Collage/university & 7 & \\
\hline Other, specify & 8 & \\
\hline
\end{tabular}

4. Could you please tell me the observed patterns of change in characteristics of your household members in the pre and post land certification periods?

Family size

Number of male adult members

Number of female adult members

Maximum education of household head

Maximum education of household member

5. What was the total farmland size of the household before land registration and certification?

6. What is the total farmland size of the household for which land certificate is provided?

Quada.

7. Do you have enough land for producing enough food crops for your household consumption? $1=$ Yes, $0=$ No

Note. ${ }^{1}$ Quada is local measuring unit for farm lands; four Quada is equivalent to one hectare 
8. Which of the following statements explain land tenure security to you?

\begin{tabular}{lll}
\hline 8.1 & Is land tenure security having a right to continually cultivate the land without outside interference? & Yes (1) \\
\hline 8.2 & Is land tenure security having a right to reap benefits of capital and labour invested in land? \\
\hline 8.3 & Is land tenure security having a right to benefit from the land temporarily transferred to others? \\
\hline 8.4 & Is land tenure security having a right to benefit from the land permanently transferred to others? \\
\hline
\end{tabular}

\section{What do you think of the following statements?}

9.1 Land certification guaranteed secure, equal and enforceable land rights to both

9.1 rich and poor farmers.

9. I am certain that the use rights given to me on arable lands will remain with me

9.2 and my family for the coming five years.

9.3 Adequate compensations will be given for the visible investments I made in my

9.3 holdings if there is future land redistribution.

9.4 Land certification ameliorated land litigation among relatives and neighbours.

9.5 Land certification guaranteed secure, equal and enforceable land rights to both

9.5 men and women farmers.

9.6 Land certification guarantees secure and enforceable formal land market

9.6 transactions.

10. Do you think that the current land tenure system is a constraint to improved agricultural production and productivity in your locality? $1=$ Yes, $0=$ No

11. Do you believe that the current land tenure system is a constraint to improved and sustainable natural resource use and management? $1=$ Yes, $0=$ No

12. Suppose land is to be privatized and you can do whatever you want with your land, do you believe that your land management practice will be changed? $1=Y e s, 0=$ No (If no, go to question number 14)

13. If yes, in what way? (Please,explain)

14. Do you think the current land holding system is good for you? $1=Y e s, 0=$ No (If no, go to question number 16)

15. If yes, in what way, if you have more than one reason, please number the reason in order of priority.

\begin{tabular}{|c|c|}
\hline & Jyou can acquire land easily \\
\hline & More secure than before \\
\hline & Have no problem of boarder conflict \\
\hline & Fair distribution of land \\
\hline & Other reason, specify \\
\hline
\end{tabular}

16. If no, which could be the reason, if you have more than one reason, please number the reason in order of priority.

\begin{tabular}{l}
\hline Fear of losing land, tenure insecurity \\
\hline Problem with local authority \\
Not being able to sell and buy \\
Injustice in land distribution \\
Not being able to get extra land \\
Could not solve land shortage \\
Other reason, specify
\end{tabular}

17. What type of house did you have before land certification? $1=$ Corrugated iron, $0=$ Grass-roofed

18. What type of house did you have currently? $1=$ Corrugated iron, $0=$ Grass-roofed

19. Did you lend at least Birr 50 to any one during the last 5 years? $1=$ Yes, $0=$ No

20. Did you adopt any non-farm own business before you received land certificate? 1=Yes, $0=$ No (If no, go to question number 22).

21 . If the answer for question 20 is yes, which activity you adopted among the following lists?

\begin{tabular}{lll}
\hline & Yes & No \\
\hline Agro-processing & $\mathbf{1}$ & $\mathbf{0}$ \\
\hline Petty trade & $\mathbf{1}$ & $\mathbf{0}$ \\
\hline Metal and woodwork & $\mathbf{1}$ & $\mathbf{0}$ \\
\hline Handicraft and construction & $\mathbf{1}$ & $\mathbf{0}$ \\
\hline Non-farm wage employment & $\mathbf{1}$ & $\mathbf{0}$ \\
\hline
\end{tabular}


22. Could you please tell me the number of livestock your household owned in the pre and post land certification periods?

23. Do you have credit access? $1=$ Yes, $0=$ No (If no, go to question number 29)

\begin{tabular}{ccccccccccc}
\hline Ox & Bull & Cow & Heifer & Calve & Sheep & Goat & Donkey & Mule & Horse & Poultry \\
\hline
\end{tabular}

Currently

Before land certificate

24. If yes, give details about it for the pre- and post- certification periods (multiple answers are possible for source, purpose, and mortgaged asset).

\begin{tabular}{|c|c|c|c|c|}
\hline Period & Source (see code) & Purpose of credit & Amount (in Birr) & Kind of asset mortgaged \\
\hline
\end{tabular}

After land

certificate

Before

land

certificate

Code for source of credit

\begin{tabular}{|c|c|c|c|}
\hline Source of credit & Code & Source of credit & Code \\
\hline State (public) bank & 1 & NGO's & 7 \\
\hline Private bank & 2 & Agricultural extension package & 8 \\
\hline Local/village money lender & 3 & Amhara credit and saving association & 9 \\
\hline Friends/Relatives & 4 & Orthodox Church & 10 \\
\hline$E q u b^{1}$ & 5 & Others, specify & 11 \\
\hline Idir $^{2}$ & 6 & & \\
\hline
\end{tabular}

25. Do you think that the amount of credit that you obtained is enough to sustainable farming? $1=$ Yes, $0=$ No

26. Do you feel that the credit facilities are adequate?

27. If no, explain why?

28. Please can you tell me the source of credit, precondition and major problems associated with the credit facilities?

\begin{tabular}{lllll}
\hline No & Source of credit (see the code in 24) & Length of credit contract (State in number of years) & Precondition & Major problem \\
\hline
\end{tabular}

1

2

3

4

5

6

29. What are the natural resource degradation problems in your locality?

\begin{tabular}{|c|c|}
\hline & Low and erratic rainfall \\
\hline & Reduced vegetation \\
\hline & Drying up of rivers \\
\hline & Soil degradation \\
\hline & Loss of wildlife \\
\hline & Bush burning \\
\hline & Jovergrazing \\
\hline & Other reason, specify \\
\hline
\end{tabular}

30. Have environmental conditions in your community improved or worsen in the last five years?

\begin{tabular}{cccccc} 
Environmental condition & $\begin{array}{c}\text { Improved } \\
\text { a lot (5) }\end{array}$ & $\begin{array}{c}\text { Improved } \\
\text { a little (4) }\end{array}$ & Same (3) & $\begin{array}{c}\text { Worsened } \\
\text { a little (2) }\end{array}$ & $\begin{array}{c}\text { Worsened } \\
\text { a lot (1) }\end{array}$ \\
\hline
\end{tabular}

30.1 Soil resource degradation

30.2 Water resource degradation

30.3 Plant resource degradation

30.4 Animal resource degradation

30.5 Overall environmental degradation

Note. ${ }^{1}$ Community or local saving association; 2Community self help association 
31. Please tell me the types of sustainable land management practice that you made on your holdings before and after receiving land certificate? (Put the answer by using $\mathrm{X}$ mark).

\begin{tabular}{|c|c|c|c|c|c|}
\hline \multirow[b]{2}{*}{ Period } & \multicolumn{5}{|c|}{ Land management practice } \\
\hline & Building terraces & Crop rotation & Planting tree & $\begin{array}{c}\text { Intercropping } \\
\text { (mixed cropping) }\end{array}$ & $\begin{array}{c}\text { Application } \\
\text { of manure }\end{array}$ \\
\hline \multicolumn{6}{|c|}{ Before land certificate } \\
\hline \multicolumn{6}{|c|}{ After land certificate } \\
\hline \multicolumn{6}{|c|}{ 32. Please tell me the number of trees and where you have planted them on your land? } \\
\hline \multirow{2}{*}{ Code } & \multirow{2}{*}{ Type (name) of tree } & \multicolumn{2}{|c|}{ Number of trees planted } & \multirow{2}{*}{\multicolumn{2}{|c|}{ Age of the oldest tree }} \\
\hline & & Homestead & Other plots & & \\
\hline 1 & Eucalyptus species & & & & \\
\hline \multicolumn{6}{|c|}{ 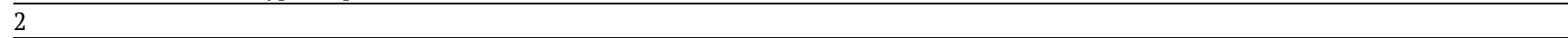 } \\
\hline \multicolumn{6}{|l|}{3} \\
\hline \multicolumn{6}{|l|}{4} \\
\hline 5 & Other, specify & & & & \\
\hline
\end{tabular}

33. Have you encountered a reason that jeopardized your sustainable land management practices in the last two years? $1=$ Yes, $0=$ No (If no, go to question number 35)

34. If Yes, please tell me the reasons that jeopardized your sustainable land management practices in the last two years. If you have more than one reason please rank the reasons in their order priority.

\begin{tabular}{|c|c|c|c|c|c|c|}
\hline \multirow[b]{2}{*}{ Possible reason } & \multicolumn{6}{|c|}{ Land management practices } \\
\hline & $\begin{array}{l}\text { Building } \\
\text { terraces }\end{array}$ & Crop rotation & Fallowing & Planting tree & $\begin{array}{l}\text { Intercropping } \\
\text { (mixed } \\
\text { cropping) }\end{array}$ & $\begin{array}{l}\text { Application of } \\
\text { manure }\end{array}$ \\
\hline
\end{tabular}

Did not have enough land

Not common around here

Did not have time to do so

Bad for the crop

Have no idea at all

Lack of credit access

Not sure about the future( tenure insecurity)

Financial incapability

Fertility of soil

Slope of the plot

Far away from my dwelling

Far away from input market

Far away from output market

Others (specify)

35. Please can you tell me the main reasons (purpose) why you undertake the under listed land management practices? If you have more than one reason, please number the reason in order of priority.

\begin{tabular}{|c|c|c|c|c|c|c|}
\hline \multirow[b]{2}{*}{ Possible reason } & \multicolumn{6}{|c|}{ Land management practices } \\
\hline & $\begin{array}{l}\text { Building } \\
\text { terraces }\end{array}$ & Crop rotation & Fallowing & Planting tree & $\begin{array}{l}\text { Intercropping } \\
\text { (mixed } \\
\text { cropping) }\end{array}$ & $\begin{array}{l}\text { Application of } \\
\text { manure }\end{array}$ \\
\hline
\end{tabular}

To enhance the productivity of land

For cultural reason

For sale

To fulfill the requirements from local

administration

To enhance tenure security

Others(specify)

36. Do you have any plan to undertake any of the above long term land management practices in the coming five years? $1=$ Yes,

$0=$ No (If no, go to question number 38)

37 . If yes, list down the types of land management practices planed? 
39. What do you think of the following statements?

\begin{tabular}{|c|c|c|c|c|c|c|}
\hline & & $\begin{array}{c}\begin{array}{c}\text { Agree a } \\
\text { lot }\end{array} \\
\end{array}$ & $\begin{array}{c}\text { Agree a } \\
\text { little }\end{array}$ & $\begin{array}{c}\begin{array}{c}\text { No } \\
\text { opinion }\end{array} \\
\end{array}$ & $\begin{array}{c}\text { Disagree } \\
\text { a little }\end{array}$ & $\begin{array}{c}\text { Disagree } \\
\text { a lot }\end{array}$ \\
\hline 39.1 & Soil erosion reduces agricultural output & 5 & 4 & 3 & 2 & 1 \\
\hline 39.2 & Soil fertility increases agricultural output & 5 & 4 & 3 & 2 & 1 \\
\hline 39.3 & Gullies and rills are manifestations of soil erosion & 5 & 4 & 3 & 2 & 1 \\
\hline 39.4 & Conservation technologies helps to reduce soil erosion & 5 & 4 & 3 & 2 & 1 \\
\hline 39.5 & Adoption of conservation technologies helps to increase agricultural output & 5 & 4 & 3 & 2 & 1 \\
\hline 39.6 & Constructing conservation technologies is a responsibility of GOs and NGOs & 1 & 2 & 3 & 4 & 5 \\
\hline 39.7 & A farmer has an obligation to construct conservation structures & 5 & 4 & 3 & 2 & 1 \\
\hline 39.8 & Farmers should be paid for construction of terraces & 1 & 2 & 3 & 4 & 5 \\
\hline 39.9 & Conservation structures have adverse effect on agricultural output & 1 & 2 & 3 & 4 & 5 \\
\hline 39.10 & Constructing conservation structures have adverse effect on household income & 1 & 2 & 3 & 4 & 5 \\
\hline 39.11 & Existing agricultural practices lead to environmental degradation & 5 & 4 & 3 & 2 & 1 \\
\hline
\end{tabular}

40. Do you think that you can easily mobilize the local economy resources to balance your deficit for adoption of conservation technologies? $1=$ Yes, $0=$ No (If yes, go to question number 42)

41. If no, what sort of challenges you anticipate in this regard?

42. Do you believe that your household is endowed with the required skills and competency to adopt conservation technologies? $1=$ Yes, $0=$ No (If no, go to question number 44)

43. If yes, to which types of technologies?

\section{If no, to which types of technologies?}

45. Have you or any member of your household received food aid in the last 15 years? $1=$ Yes, $0=$ No. If yes, how many times and in which years?

46. Were you included in the current extension program? $1=$ Yes, $0=$ No. If yes, what sort of advice is available and how effective are these advices?

\begin{tabular}{llllcll}
\hline \multirow{2}{*}{ No } & \multirow{2}{*}{ Type of advices } & \multicolumn{4}{c}{ Extent of effectiveness } \\
\cline { 3 - 6 } & Very good (5) & Good (4) & Not good (3) & Bad (2) & Very bad (1) \\
\hline
\end{tabular}

\begin{tabular}{llllll}
\cline { 2 - 5 } & Very good (5) & Good (4) & Not good (3) & Bad (2) & Very bad (1) \\
\hline
\end{tabular}

47. What is the distance between your home and the two closest markets you frequently use for marketing your output/inputs?

\begin{tabular}{lcc} 
Markets & Name of the market & Distance in local units (hours on foot....) \\
\hline
\end{tabular}

The closest market

The next closest market

48. What are the most serious agricultural problems of farmers in your community?

(Multiple answer is possible but rank them according to their order of importance)

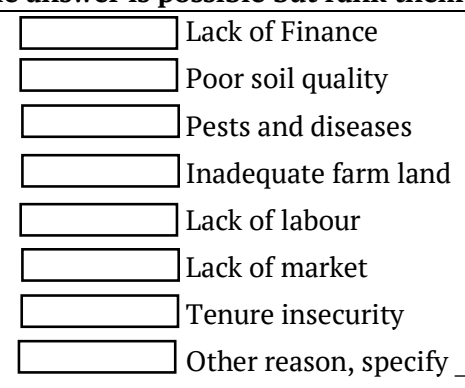

49. Do you experience any catastrophic shock before you received land certificate? $1=$ Yes, $0=$ No

50. What shock has your household experienced in the last 6 years and what impact did this shock have?

\begin{tabular}{|c|c|c|c|c|}
\hline & \multirow{2}{*}{ Yes } & \multirow{2}{*}{ No } & \multicolumn{2}{|c|}{ Loss of assets due to shock } \\
\hline & & & Yes & No \\
\hline Any shock & 1 & 0 & 1 & 0 \\
\hline Weather & 1 & 0 & 1 & 0 \\
\hline Pest and diseases & 1 & 0 & 1 & 0 \\
\hline Illness and death of family member & 1 & 0 & 1 & 0 \\
\hline Loss of livestock & 1 & 0 & 1 & 0 \\
\hline
\end{tabular}


51. What is/are the main source(s) of energy for cooking in your household?

52. Could you please, tell me your last year annual expenditure on the following items?

\begin{tabular}{ll}
\hline Code & Expenditure category \\
\hline 1 & Agriculture related \\
\hline 2 & Household food consumption \\
\hline 3 & Household school expenses \\
\hline 4 & Household health expenses \\
\hline 5 & Household clothing expenses \\
\hline 6 & Household expenses in social events \\
\hline 7 & Household tax payments \\
\hline 8 & Household other expenses (specify) Birr \\
\hline $\mathbf{5 3 .}$ Could you please, tell me the status of your and any household members participation or affiliation with the following institutions? \\
\hline Code $\quad$ Institution \\
\hline $1 \quad$ Kebele council \\
\hline 2 & Equb \\
\hline 3 & Idir \\
\hline 4 & Mahiber \\
\hline 5 & Senbete \\
\hline 6 & Cooperative \\
\hline 7 & Political party \\
\hline 8 & Other institutions (specify) \\
\hline $\mathbf{5 4}$ Do you have any suggestions, comments, or advises you would like to make on the current land tenure system?
\end{tabular}

